\title{
Changes in chemical constituents and overall acceptability of papaya jam fortified with soya protein during storage
}

\author{
Perubahan karakteristik kimia dan tingkat penerimaan dari selai pepaya yang difortifikasi dengan protein \\ kedelai selama masa penyimpanan \\ Dimas Bayu PINANDOYO \& Asriadi MASNAR ${ }^{*}$
}

Department of Packaging Technology, State Polytechnic of Creative Media, Jl. Srengseng Sawah No.17, Jagakarsa, Jakarta 12630, Indonesia.

Diterima tgl 26 Februari 2020 / disetujui tgl 28 April 2020

\begin{abstract}
Abstrak
Produk buah olahan umumnya mengandung protein yang sangat rendah akibat proses pemanasan selama pembuatannya. Tulisan ini menyajikan hasil penelitian mengenai peningkatan nilai gizi selai pepaya melalui fortifikasi menggunakan konsentrat protein kedelai. Selai pepaya disiapkan dengan perbandingan 40: 1, 40:2, 40: 3, 40: 4, dan 40:5 (v/v) antara bubur pepaya dan konsentrat protein kedelai. Pada perlakuan perbandingan dengan tingkat penerimaan tertinggi kemudian dilakukan analisis karakteristik kimia dan tingkat penerimaan setiap bulan selama tiga bulan penyimpanan. Karakter kimia yang dianalisis adalah kadar air, total padatan terlarut (TSS), pH, gula total, gula pereduksi, pencokelatan nonenzimatik, keasaman, asam askorbat, total karotenoid, total fenol, protein kasar, dan total plate count (TPC). Hasil penelitian menunjukkan bahwa selai pepaya yang telah difortifikasi dengan perbandingan konsentrat pulp dan protein kedelai 40: 1 memiliki tingkat penerimaan tertinggi. Selama proses penyimpanan menunjukkan bahwa kadar air, TSS, pH, gula total dan pereduksi, dan pencokelatan non-enzimatik meningkat, sementara tingkat keasaman, asam askorbat, total karotenoid, fenol, total antioksidan dan kandungan protein kasar selai menurun. Fortifikasi selai pepaya dengan konsentrat protein kedelai (40:1 v/v) meningkatkan kandungan protein kasar rata-rata dari 3,15\% menjadi 4,16\%. Total plate count (TPC) menunjukkan bahwa tidak ada kontaminasi mikroba selama periode penyimpanan 3 bulan. Disimpulkan bahwa selai pepaya yang mengandung konsentrat protein kedelai tetap dapat diterima selama penyimpanan meskipun tingkat penerimaan menurun seiring dengan waktu.
\end{abstract}

[Kata kunci: aktivitas antioksidan, fortifikasi makanan, formulasi selai, kadar air, evaluasi sensorik]

*) Penulis korespondensi: asriadi.masnar@polimedia.ac.id

\begin{abstract}
Processed fruit products commonly contain very low protein due to the heat treatment during processing period. This article presents the research results concerning the increase of nutrition value of papaya jam fortified with soya protein concentrate. Papaya jam prepared with ratio 40:1, 40:2, 40:3, $40: 4$, and $40: 5(\mathrm{v} / \mathrm{v})$ of papaya pulp and soya protein concentrate. The treatment of papaya jam and soya protein with the highest acceptability was then analyzed for the changes in chemical constituents and overall acceptability at monthly interval during three months of storage. The parameters that being analyzed were moisture content, total soluble solids (TSS), $\mathrm{pH}$, total and reducing sugars, non-enzymatic browning, acidity, ascorbic acid, total carotenoid, total phenol, crude protein, and total plate count. The results showed that fortified papaya jams prepared with papaya pulp and soy protein concentrate ratio at $40: 1$ had the highest acceptability. During storage time it revealed that moisture content, TSS, $\mathrm{pH}$, total and reducing sugars, and non-enzymatic browning increased, while acidity, ascorbic acid, total carotenoids, phenols, total antioxidants and crude protein contents of jam decreased. Fortification of papaya jam with soya protein concentrate (40:1 v/v) increased crude protein content on average from $3.15 \%$ to $4.16 \%$. Total plate count (TPC) indicated that no microbial contamination during 3 months storage period. It can be concluded that papaya jam fortified with soya protein concentrate remained acceptable during storage although the acceptability decreased over time.
\end{abstract}

[Keywords: antioxidant activity, food fortification, jam formulation, moisture content, sensory evaluation] 


\section{Introduction}

Protein has known to have an important role structurally and functionally in human live. As structural role, protein provides strength and shape of cells or tissues such as cartilage. While, as functional role, protein has diverse roles depending on the structure, such as enzymes. Lacking of protein on human diet may cause severe weight lost, malfunction in growth, protein energy deficiency, and kwashiorkor (Wu, 2016; Pinandoyo et al., 2019).

At least $20 \%$ of human global population were vegetarians in 2010. The number of vegetarians has been increased slightly compared to that of in 2002, but it indicated the trend was increasing each year (Leahy et al., 2010). Vegetarian life-style often complemented with other healthy life style habits such as no-smoking, no-alcohol, and use of alternative therapies that proved to be more natural and cheaper than the ordinary ones. Furthermore, in social situations, identity was an important factor that affects dietary habits with reduced meatconsumption particularly in their adolescence stage (Gulliksen, 2018).

Jam has been commonly consumed as one of breakfast menu especially in India as a vegetarian country. Papaya jam has a high popularity, whether produced as mixed- or originally jams. It was claimed that jams, especially papaya jam, provide good energy with half bout of calories since the present of fibre and fructose that will maintain the sugar level and satisfied level of the consumers (Gupta et al., 2016).

Papaya provides a good nutritional value, and can be easily processed to a wide variety of food products. It contains pro-vitamin $\mathrm{A}$, carotenoids average of $232 \mu \mathrm{g} \beta$-carotene and $594 \mu \mathrm{g} \beta$ cryptoxanthin and vitamin A ranged from 18 to 74 $\mu \mathrm{g}$ RAE (retinol activity equivalents) per $100 \mathrm{~g}$. Lycopene content in the red-fleshed papaya varieties ranged from 1350-3674 $\mu \mathrm{g} / 100 \mathrm{~g}$ (Luximon-Ramma et al., 2003). The vitamin $\mathrm{C}$ content was approximately $50 \mathrm{mg} / 100 \mathrm{~g}$ (Boshra \& Tajul, 2013). Many papaya producing countries are facing difficulties since the fruits were very prone to physical stress. Post-harvest loss of papaya can reach $40 \%$ of the harvest (Oksuz et al., 2015). Due to this high susceptibility, papaya is commonly served as papaya products such as juices, blended beverages, jam (including low calorie), jelly, dehydrated, osmodried, fruit bar, candy, and frozen products. Moreover, previous study showed that hexanal could extend papaya shelf-life until 6 days (Hutchinson et al., 2018) .

Papaya jam still preserve some nutritional values of papaya fruit. However, the protein content of papaya jam was very low. Since papaya jam is commonly popular in developing countries, fortification of protein is recommended. WHO guideline in fortification stated that fortification against protein energy malnutrition should be prioritised especially in the developing countries (WHO, 2006). Fortification of protein in papaya jam may increase the nutritional and health values of papaya jam. However, adding protein to fruit product may affect the characteristics and acceptability of fruit products since protein powder is not easily soluble in acid condition like most of fruit products (Anju et al., 2014). This research aimed to investigate the proper formula of fortification in papaya jam using soya protein concentrate.

\section{Materials and Methods}

\section{Sample materials}

Ripe papaya fruits cv. Disco and soya flour were obtained from the local market in Hisar, Haryana, India. Papaya fruits were extracted to produce pulp as the main material for papaya jam, while soya flour was used as the main material to make protein concentrate. The chemicals used for analysis were obtained from chemical stock of the Centre of Food Science and Technology, Chaudhary Charan Singh Haryana Agricultural University, Hisar, Haryana, India.

In order to obtain the papaya pulp, the papaya fruits were washed thoroughly with clean running water and cut into slices with a stainless steel knife. The papaya and sodium benzoate $\left(\mathrm{C}_{6} \mathrm{H}_{5} \mathrm{COONa}\right)(1$ $\mathrm{g} / \mathrm{kg}$ ) were then ground in a grinder.

Soya protein concentrate was made according to Wang's method (Wang et al., 2004). Briefly, soy flour was mixed in water $(1: 10 ; \mathrm{v}: \mathrm{v})$. After mixed, the $\mathrm{pH}$ was set to 4 by adding $1 \mathrm{M} \mathrm{HCl}$. Residue was kept and washed with distilled water. After that, the $\mathrm{pH}$ was adjusted to 7 by adding $1 \mathrm{M} \mathrm{NaOH}$. The mixture was settled and the residue was washed with distilled water to remove the $\mathrm{NaOH}$ residue. Distilled water was added by ratio of $1: 10(\mathrm{v} / \mathrm{v})$ and the mixture was centrifuged at $3000 \mathrm{rpm}$ for $15 \mathrm{~min}$. The residue was kept overnight in hot air oven at 55-60 ${ }^{\circ} \mathrm{C}$. The dried flakes were grinded into very fine flour, sieved at $280 \mu \mathrm{m}$, packed in polyethylene bags, sealed and stored in a refrigerator for further analysis.

\section{Jam production}

For each kilogram of papaya pulp, $700 \mathrm{~g}$ sugar, $4 \mathrm{~g}$ citric acid, and $2 \mathrm{~g}$ pectin were added. The mixture was cooked with constant stirring until thick consistency has been achieved. End point was judged by sheet test and measuring total soluble solids (68\%) using hand refractometer (58-92\%). The product was packed in $150 \mathrm{~g}$ capacity sterilized glass jars and then stored. 


\section{Formulation of fortified jam and experimental design}

The experiment was arranged using a Completely Randomized Design (CRD) in this following treatments:

i) 40 parts papaya pulp: 1 parts soy concentrate

ii) 40 parts papaya pulp: 2 parts soy concentrate

iii) 40 parts papaya pulp: 3 parts soy concentrate

iv) 40 parts papaya pulp: 4 parts soy concentrate

v) 40 parts papaya pulp: 5 parts soy concentrate

As control, $100 \%$ papaya pulp without addition of concentrate was used as material of jam. Gelling characteristic and the result of sensory evaluation for each combination was used to determine which proportion that would be further analysed for chemical constituents and acceptability during storage period.

\section{Chemical analysis}

Total soluble solids (TSS) of the fruit and jam calculated in ${ }^{\circ}$ Brix were determined using Abbe refractometer (Bausch and Lomb, Switzerland). Samples were placed on the sample holder of the refractometer that had been standardized to the zero mark with distilled water. The refractive index and ${ }^{\circ}$ Brix were read from the refractometer. $\mathrm{pH}$ was determined using $\mathrm{pH}$ meter (model BA 350 EDT instruments, UK). Moisture content was analyzed using oven method. Acidity level, ascorbic acid content, total phenolic content, and crude protein content were analyzed using AOAC standard method (AOAC, 1990). Total and reducing sugars were analyzed using Hulme and Narain's method (Hulme \& Narain, 1931), while total carotenoid was determined according to Rivera-Vélez (2016) and Rodriguez-Amaya (2001). Antioxidant activity was measured using 2,2-diphenyl-1-picrylhydrazyl (DPPH) method. Non-enzymatic browning was recorded for fresh and stored products according to Rangnna (2007). In order to investigate the microbial contamination during storage, total plate count (TPC) in a serial dilution technique was used.
Organoleptic evaluation was conducted using 9 (nine) level of hedonic scale on 15 semi trained panelists. Data were taken in three replications. All the data were collected during 3 months of storage time.

\section{Statistical analysis}

In order to investigate the significantly effect of treatment, all collected data were subjected to analysis of variance (ANOVA) at $\alpha=0.05$.

\section{Results and Discussion}

\author{
Formula of soya protein concentrate fortified \\ papaya jam
}

Fortification of protein in fruit products may affect their acceptability and characteristics. Formulation is the key to ensure that the fortification of protein will not significantly change the characteristics of the fruit products and the products still have a good acceptability to the consumers (Karanjalker et al., 2013; Anju et al., 2014; Kaul, 2017). In this research, the characteristic of jam produced with various combinations of papaya pulp and soy concentrate is shown in Table 1. The results then had been justified using the standard described by CODEX STAN 296. Products had soft even consistency without distinct pieces of fruit, bright color, good fruit flavor, semi-jellied texture without free liquid, and easy to spread would be subjected to further analysis.

Based on the CODEX STAN 296 standard, the results showed that only control (100\% papaya pulp) and treatment with combination of 40:1 and 40:2 papaya pulp: soya protein concentrate were acceptable. These two combinations and the control had appropriate gelled consistency, normal colour and flavour. The combination of 40:1, 40:2 and control showed glossy, a little pasty, soft gel, a little sticky, and a little loose characteristics. The ratio of 40:1 and 40:2 showed acceptable jam while other combinations did not performed a proper formation of jam. The protein addition in fruit product was

Table 1. Characteristics of jam prepared from different combinations of papaya pulp and soybean concentrate Tabel 1. Karakteristik selai yang berasal dari beberapa kombinasi bubur pepaya dan konsentrat kedelai

\begin{tabular}{lcccc}
\hline \multicolumn{2}{c}{$\begin{array}{c}\text { Treatments combinations/ } \\
\text { Kombinasi perlakuan } \\
\text { Ratio/ Nisbah } \\
(\mathrm{v} / \mathrm{v})\end{array}$} & & \multicolumn{2}{c}{ Descriptive attributes of jam/ Deskripsi sifat selai } \\
\cline { 3 - 5 } & & Appearance/ Tampilan & Texture/ Tekstur & State/ Kondisi \\
\hline Control [papaya]/ Kontrol [pepaya] & 100 & Glossy, tender & Soft, gel & A little loose \\
Papaya: soya concentrate/ & $40: 1$ & Glossy, tender & Soft, gel & A little loose \\
Pepaya: konsentrat kedelai & $40: 2$ & Glossy, a little pasty & Soft, gel, a little sticky & A little loose \\
& $40: 3$ & Cloudy, pasty & Soft, sticky & Loose \\
& $40: 4$ & Dull, pasty & Hard, sticky & Loose \\
& $40: 5$ & Dull, very pasty & Hard, very sticky & Firm \\
\hline
\end{tabular}


difficult due to insoluble in acid conditions, so the persistence and gelling characteristic may be affected. This also involved in Maillard reaction and may also affect fruit product appearance (Anju et al., 2014; Sharma et al., 2016).

For further analysis, papaya jam that prepared from combination of 40:1 and 40:2 were subjected to sensory test. The results showed that fortified papaya jam with soya protein concentrate ratio of 40:1 had a higher acceptability than that of 40:2 (Table 2). Soya protein concentrate was good in complementing food with high protein content but low production cost. According to Mao \& Hua (2012) these characteristics give a strong taste and odor and may affect the taste of incorporated product. In our research, the combination of 40:1 did not affect the taste of product, thus this formula would be used for further analysis.

\section{Changes of chemical constituents of papaya jam $\mathrm{pH}$}

During storage, $\mathrm{pH}$ of both control and treatment were increased. The $\mathrm{pH}$ was affected by fortification of soya protein concentrate (Table 3 ). Average of $\mathrm{pH}$ in control during storage time was 3.50, while treatment showed average of $\mathrm{pH}$ was 3.14 . In the fruit product, $\mathrm{pH}$ was affected by ascorbic acid and polyphenol content and during storage time both factors were hydrolyzed. This degradation occurred because the increasing of $\mathrm{pH}$ value (Gomes et al., 2014). In soya protein concentrate fortified papaya jam, protein that being added was hydrolyzed to amino acid resulting lower $\mathrm{pH}$ compared to control. The $\mathrm{pH}$ and acidity were characteristic that responsible for astringency of fruit product. Change of $\mathrm{pH}$ and acidity need to be observed to decide whether the fortification will affect the final taste of product or not, especially in astringency aspect.

\section{Ascorbic acid}

Ascorbic acid of fortified papaya jam and control decreased during storage time. Fortification of protein in this research affected the ascorbic acid content of papaya jam. Ascorbic acid of papaya jam was lower than that of the control (Table 3). Ascorbic acid is easily oxidized by heat, light, enzymes, or oxygen. According to Bhardwaj \& Mukherjee (2011) ascorbic acid content was decreased during storage time. The ascorbic acid content of fortified papaya jam was lower than that of control might be caused by the involvement of Maillard reaction preventing. Ascorbic acid provided optional substrate to be oxidized to generate dehydro-ascorbic acid and then finally furfural compound instead of forming brown pigments (Kuchi et al., 2014). The evidence was supported by a lower occurrence in non-enzymatic browning in fortified papaya jam.

Table 2. Sensory score (on 9-point hedonic scale) of jam prepared from different combinations of papaya pulp and soya concentrate

Tabel 2. Skor sensoris (pada skala hedonis angka-9) dari selai kombinasi bubur pepaya dan konsentrat kedelai

\begin{tabular}{lccccc}
\multicolumn{2}{c}{$\begin{array}{c}\text { Treatments combination/ } \\
\text { Kombinasi perlakuan }\end{array}$} & $\begin{array}{c}\text { Colour and } \\
\text { appearance/ } \\
\text { Warna dan tampilan }\end{array}$ & $\begin{array}{c}\text { Aroma/ } \\
\text { Aroma }\end{array}$ & $\begin{array}{c}\text { Taste/ } \\
\text { Rasa }\end{array}$ & $\begin{array}{c}\text { Overall acceptability/ } \\
\text { Total penerimaan }\end{array}$ \\
\hline $\begin{array}{l}\text { Papaya : soy concentrate/ } \\
\begin{array}{l}\text { Pepaya: } \text { konsentrat } \\
\text { kedelai }\end{array}\end{array}$ & $40: 1$ & 8.6 & 7.9 & 8.0 & 8.2 \\
\hline
\end{tabular}

Table 3. Changes of chemical constituents that affect astringency

Tabel 3. Perubahan kimiawi yang mempengaruhi keasaman

\begin{tabular}{|c|c|c|c|c|c|c|}
\hline \multirow{2}{*}{$\begin{array}{c}\text { Storage time/ } \\
\text { Lama } \\
\text { penyimpanan } \\
\text { (Month/Bulan) }\end{array}$} & \multicolumn{2}{|c|}{ pH/ Derajat keasaman } & \multicolumn{2}{|c|}{$\begin{array}{c}\text { Acidity/ Keasaman } \\
(\%)\end{array}$} & \multicolumn{2}{|c|}{$\begin{array}{c}\text { Ascorbic acid/ Asam askorbat } \\
(\mathrm{mg} / 100 \mathrm{~g})\end{array}$} \\
\hline & $\begin{array}{l}\text { Fortified product/ } \\
\text { Produk fortifikasi }\end{array}$ & $\begin{array}{l}\text { Control/ } \\
\text { Kontrol }\end{array}$ & $\begin{array}{l}\text { Fortified Product/ } \\
\text { Produkfortifikasi }\end{array}$ & $\begin{array}{l}\text { Control/ } \\
\text { Kontrol }\end{array}$ & $\begin{array}{l}\text { Fortified Product/ } \\
\text { Produk fortifikasi }\end{array}$ & $\begin{array}{l}\text { Control/ } \\
\text { Kontrol }\end{array}$ \\
\hline 0 & 2.98 & 3.27 & 0.48 & 0.53 & 34.5 & 39.3 \\
\hline 1 & 3.01 & 3.41 & 0.45 & 0.50 & 30.5 & 31.1 \\
\hline 2 & 3.20 & 3.55 & 0.42 & 0.48 & 25.9 & 27.9 \\
\hline 3 & 3.41 & 3.76 & 0.40 & 0.46 & 21.0 & 24.2 \\
\hline Mean/Rata-rata & 3.14 & 3.50 & 0.44 & 0.50 & 28.0 & 30.6 \\
\hline $\mathrm{CV}$ at $5 \%$ & \multicolumn{2}{|l|}{ NS } & \multicolumn{2}{|c|}{ NS } & \multicolumn{2}{|c|}{ NS } \\
\hline
\end{tabular}

Notes/ Keterangan:

$\mathrm{CV}=$ Coefficient of Variation/ Koefisien Keragamani

NS= Non Significant/ Tidak Nyaa . 
Acidity

Acidity was affected by fortification of soya protein concentrate. All fortified products had lower acidity than that of control (Table 3). Acidity of both control and treatments were decreased during storage time. The increasing of acidity might be ascribed to rise in the concentration of weakly ionized acids by degradation of polysaccharides and oxidation of reducing sugars or by break down of pectic substances and uronic acid. The increase of $\mathrm{pH}$ also indicated by reducing in acidity level (Jiang et al., 2018).

\section{Total sugar}

Total sugar of fortified papaya jams were slightly lower than that of control during storage time (Table 4). In addition, during storage time, TSS of control and fortified products were also increased. The increasing of total sugar might be due to the hydrolysis of polysaccharides such as pectin, starch, and others into simple sugars (Madeira-Nunes et al., 2007; Menezes et al., 2011). Sugar content of jam not only affected the sweetness level, but also gelling characteristic. Furthermore, sugar content may also affected the water content of jam. If total sugar is too high, the jam will have harder texture, while lower sugar content may lead to syneresis causing a loose consistency of jam (CODEX STAN 296).

\section{Moisture content}

During 3 months of storage, the moisture contents of fortified papaya jam have been decreased steadily (Table 4). The moisture content between control $(31.05 \%)$ and fortified products $(31.00 \%)$ was not significantly different. The decreasing of the moisture might occur due to utilization of free water in polysaccharides hydrolysis into monosaccharides and oligosaccharides (Majumdar \& Chattopadhyay, 2011). The moisture content in jam might decrease or increase depending on the temperature and humidity of the storage. Changes in moisture was commonly happened in jam during storage time (Ajenifujah-Solebo \& Aina, 2011). Moisture content of jam should to be observed since protein may binds the water molecules inside the jam so that it will affect the jam characteristics.

TSS of both control and fortified jams increased during storage time (Table 4). TSS of fortified jam $(68.4 \%)$ was not different than that of the control $(68.5 \%)$. The increasing of TSS during storage may be caused by hydrolysis of polysaccharides and oligosaccharides (Majumdar \& Chattopadhyay, 2011). The result of this study was in accordance with previous research studies in mango jam (Nour et al, 2011; Safdar et al., 2012), karonda jam (Wani et al., 2013) and jamun-mango blended jam (Sharma et al., 2016).

\section{Reducing sugar}

Unlike total sugar, reducing sugar of fortified jam $(33.8 \%)$ was slightly higher than that of control $(33.0 \%)$ (Table 4). The reducing sugar of both fortified jam and control increased during storage time. The increase in reducing sugar content during storage was mainly due to the inversion of nonreducing sugars into reducing sugars (Bons \& Dhawan, 2013). Reducing sugar may affect to the appearance and aroma characteristics of jam. According to Asikin et al. (2014) this involved in Maillard reaction that produce brownish colour and baked-like aroma. Based on this the reducing sugar needed to be measured in this research.

Table 4. Changes of chemical constituent that affect jelling characteristic and consistency

Tabel 4. Perubahan komposisi kimiawi yang memengaruhi karakter dan konsistensi selai

\begin{tabular}{|c|c|c|c|c|c|c|c|c|}
\hline \multirow{2}{*}{$\begin{array}{c}\text { Storage time/ } \\
\text { Lama } \\
\text { penyimpanan } \\
\text { (Month/Bulan) }\end{array}$} & \multicolumn{2}{|c|}{$\begin{array}{c}\text { Moisture content/ } \\
\text { Kadar air } \\
(\%)\end{array}$} & \multicolumn{2}{|c|}{$\begin{array}{l}\text { Total soluble solid } \\
\text { (TSS)/ } \\
\text { Total padatan terlarut } \\
(\%)\end{array}$} & \multicolumn{2}{|c|}{$\begin{array}{c}\text { Total sugar/ Gula total } \\
(\%)\end{array}$} & \multicolumn{2}{|c|}{$\underset{(\%)}{\text { Reducing sugar/ Gula reduksi }}$} \\
\hline & $\begin{array}{l}\text { Fortified } \\
\text { product/ } \\
\text { Produk } \\
\text { fortifikasi }\end{array}$ & $\begin{array}{l}\text { Control/ } \\
\text { Kontrol }\end{array}$ & $\begin{array}{l}\text { Fortified } \\
\text { product/ } \\
\text { Produk } \\
\text { fortifikasi }\end{array}$ & $\begin{array}{l}\text { Control/ } \\
\text { Kontrol }\end{array}$ & $\begin{array}{l}\text { Fortified } \\
\text { product/ } \\
\text { Produk } \\
\text { fortifikasi }\end{array}$ & $\begin{array}{l}\text { Control/ } \\
\text { Kontrol }\end{array}$ & $\begin{array}{l}\text { Fortified } \\
\text { product/ } \\
\text { Produk } \\
\text { fortifikasi }\end{array}$ & $\begin{array}{l}\text { Control/ } \\
\text { Kontrol }\end{array}$ \\
\hline 0 & 31.45 & 31.51 & 68.0 & 68.0 & 52.9 & 54.1 & 33.4 & 32.5 \\
\hline 1 & 31.14 & 31.18 & 68.2 & 68.2 & 53.3 & 54.4 & 33.6 & 32.7 \\
\hline 2 & 30.89 & 30.93 & 68.5 & 68.6 & 53.9 & 55.0 & 33.9 & 33.2 \\
\hline 3 & 30.54 & 30.57 & 68.8 & 69.0 & 54.5 & 55.5 & 34.3 & 33.6 \\
\hline Mean/ Rata-rata & 31.00 & 31.05 & 68.4 & 68.5 & 53.4 & 54.5 & 33.8 & 33.0 \\
\hline $\mathrm{CV}$ at $5 \%$ & \multicolumn{2}{|c|}{ NS } & \multicolumn{2}{|c|}{ NS } & \multicolumn{2}{|c|}{ NS } & \multicolumn{2}{|c|}{ NS } \\
\hline
\end{tabular}




\section{Non-enzymatic browning}

Non-enzymatic browning of fortified jam was observed slighly lower than that of control (Table 5). During storage, non-enzymatic browning of fortified jam and control increased gradually. Theoretically, the addition of protein to papaya jam should increase the non-enzymatic browning reaction. However, it may affect contradictory since the presence of antioxidant agent in jam, such as ascorbic acid and phenols (Kuchi et al., 2014). Conversion of nonreducing to reducing sugars also increased the potential susceptibility of processed papaya products to non-enzymatic browning during high-temperature or prolonged storage conditions (Barlianti et al., 2016).

\section{Total carotenoid content}

Total carotenoid of control was slightly higher than that of fortified jam (Table 5). During storage time, total carotenoid of both control and fortified jam have been decreased with the prolonged the storage time. Total carotenoid was responsible to the color formation of papaya jam. The presence of Maillard reaction might affect the appearance. This research result showed that the fortification did not significantly affect to the appearance of papaya jam.

\section{Total phenol}

Total phenol content in fortified papaya jam was the same as control (Table 5). Total phenols of both control and fortified jam decreased during storage.
Phenol compounds are easily oxidized and very volatile. They will be decreased during storage time regardless of environmental or chemical factors of food products (Shahidi \& Ambigaipalan, 2015). Similar decreased in total phenols were also reported in jamun jam (Singh \& Siddiqui, 2010), blueberry jam (Fracassetti et al., 2013), strawberry jam (Poiana et al., 2011), and araça (Brazilian guava) jam (Damiani et al., 2012).

\section{Crude protein}

Fortification of soya protein concentrate in papaya jam significantly increased the protein value by up to $32.06 \%$. Crude protein content of fortified product was $4.16(\% \mathrm{dwb})$ and control was $3.15(\%$ dwb) (Tabel 5). Crude protein contents of both fortified product and control decreased as the longer of storage time. Protein fortification of fruit product has been a problem regarding to protein solubility in acid environment. In some cases, the protein addition showed no efficiency at all. Previous study has also been carried out on protein fortification, such as: in guava jam (Perez-Rocha et al., 2015). When exposed to excess of protein fortification, fruit products had of lower acceptance from the consumers (Khan et al., 2012). Our research showed that fortification with soya protein concentrate at the ratio (40:1) still had an impact on protein content of papaya jam. The decreasing of protein during storage time may happened due to degradation of protein into amino acids (Paramita et al., 2010).

Table 5. Changes of chemical constituents in term of nutrition factor Tabel 5. Perubahan kandungan kimia terkait faktor nutrisi

\begin{tabular}{|c|c|c|c|c|c|c|c|c|}
\hline \multirow{2}{*}{$\begin{array}{l}\text { Storage time/ } \\
\text { Lama } \\
\text { penyimpanan } \\
\text { (Month/Bulan) }\end{array}$} & \multicolumn{2}{|c|}{$\begin{array}{c}\text { Non-enzymatic browning/ } \\
\text { Warna coklat bukan } \\
\text { pengaruh enzim } \\
\text { (OD at } 440 \mathrm{~nm})\end{array}$} & \multicolumn{2}{|c|}{$\begin{array}{l}\text { Total carotenoid/ } \\
\text { Karotenoid total } \\
\quad(\mathrm{mg} / 100 \mathrm{~g})\end{array}$} & \multicolumn{2}{|c|}{$\begin{array}{l}\text { Total phenol/ } \\
\text { Total fenol } \\
\text { (mg/100g) }\end{array}$} & \multicolumn{2}{|c|}{$\begin{array}{l}\text { Crude protein/ } \\
\text { Protein kasar } \\
(\% \text { dwb })^{*}\end{array}$} \\
\hline & $\begin{array}{c}\text { Fortified } \\
\text { product/ } \\
\text { Produk } \\
\text { fortifikasi }\end{array}$ & $\begin{array}{l}\text { Control/ } \\
\text { Kontrol }\end{array}$ & $\begin{array}{l}\text { Fortified } \\
\text { product/ } \\
\text { Produk } \\
\text { fortifikasi }\end{array}$ & $\begin{array}{l}\text { Control/ } \\
\text { Kontrol }\end{array}$ & $\begin{array}{c}\text { Fortified } \\
\text { product/ } \\
\text { Produk } \\
\text { fortifikasi } \\
\end{array}$ & $\begin{array}{l}\text { Contro/ } \\
\text { Kontrol }\end{array}$ & $\begin{array}{c}\text { Fortified } \\
\text { product/ } \\
\text { Produk } \\
\text { fortifikasi }\end{array}$ & $\begin{array}{c}\text { Control/ } \\
\text { Kontrol }\end{array}$ \\
\hline 0 & 0.067 & 0.070 & 2.88 & 2.98 & 0.56 & 0.57 & 4.28 & 3.26 \\
\hline 1 & 0.072 & 0.079 & 2.81 & 2.88 & 0.54 & 0.53 & 4.18 & 3.19 \\
\hline 2 & 0.088 & 0.098 & 2.74 & 2.80 & 0.52 & 0.51 & 4.11 & 3.10 \\
\hline 3 & 0.098 & 0.102 & 2.63 & 2.72 & 0.50 & 0.50 & 4.06 & 3.05 \\
\hline Mean/ Rata-rata & 0.081 & 0.086 & 2.77 & 2.85 & 0.53 & 0.53 & 4.16 & 3.15 \\
\hline $\mathrm{CV}$ at $5 \%$ & \multicolumn{2}{|c|}{ NS } & \multicolumn{2}{|c|}{ NS } & \multicolumn{2}{|c|}{ NS } & \multicolumn{2}{|c|}{0.12} \\
\hline $\begin{array}{l}\text { Notes/ Keterangan } \\
\text { *Protein fortificatic } \\
\mathrm{CV}=\text { Coefficient } \mathrm{o} \\
\mathrm{NS}=\text { Non Signific }\end{array}$ & $\begin{array}{l}\text { riation/ Koe } \\
\text { Tidak Nyata }\end{array}$ & eragaman & 807 & enta & 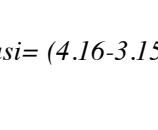 & $215 \mathrm{~V}$ & $=32.06$ & \\
\hline
\end{tabular}




\section{Total plate count}

In order to investigate the presence of microbial contamination, the plate count method was applied. The results showed that no microbial growth in both of control and fortified jams during storage time up to 3 months. Jam must be free from microbial contaminantion, bacterial and fungal toxins for at least 6 months storage time (Rawat, 2015). The right handling may be the key to prevent microbial growth in fruit product. However, microbial growth in jam products might be prevented by a high concentration of sugar.

\section{Overall acceptability}

Sensory evaluation showed that overall acceptability of both fortified product and control were decreased as the longer of the storage period (Table 6). Fortified papaya jam had a slightly lower acceptability than that of control during storage time (Table 6), but the difference was not significant. With fortification of soya protein concentrate in papaya jam was proved to the final output. The papaya jam still had acceptability similar to conventional papaya jam (control).

In term of color, the addition of protein might enhance the Maillard reaction of papaya jam resulting decreased acceptability on color. Formulated fortification of soya protein concentrate showed no significantly difference in this term so that the acceptability was still in the range almost the same as the control. Changes in chemical factor that involved in astringency also not significantly affected the final taste of the products. However, some contents like ascorbic acid and total phenol might be affected. The reason might be due to the involvement of both factors in retention of original taste and color of fortified papaya jam.

Table 6. Overall acceptability and microbial content Tabel 6. Tingkat penerimaan dan kandungan mikroba

\begin{tabular}{ccc}
\hline & \multicolumn{2}{c}{$\begin{array}{c}\text { Overall acceptability/ } \\
\text { Tingkat penerimaan }\end{array}$} \\
\cline { 2 - 3 } $\begin{array}{c}\text { Lama penyimpanan } \\
\text { (Month/ Bulan) }\end{array}$ & $\begin{array}{c}\text { Fortified } \\
\text { product/ } \\
\text { Produk } \\
\text { fortifikasi }\end{array}$ & $\begin{array}{c}\text { Control/ } \\
\text { Kontrol }\end{array}$ \\
\hline 0 & 8.5 & 8.6 \\
1 & 8.2 & 8.4 \\
2 & 7.9 & 8.3 \\
3 & 7.8 & 8.0 \\
\hline Mean/ Rata-rata & 8.0 & 8.3 \\
\hline CV at 5\% & \multicolumn{2}{c}{ NS } \\
\hline
\end{tabular}

Notes/ Keterangan:

$\mathrm{CD}=$ Coefficient of Variation/ Koefisien Keragaman

NS $=$ Non Significant $/$ Tidak Nyata

\section{Conclusion}

Fortification of soya concentrate protein in papaya jam with the highest acceptability was formulated using proportion papaya pulp and soya concentrate of $40: 1$. With this composition, the moisture content, TSS, total sugar, reducing sugar, and total carotenoid content of fortified papaya jam were not significantly different from control. Whereas, acidity, $\mathrm{pH}$, ascorbic acid, and total phenol were still be affected slightly, but these did not significantly affected in overall acceptability. During storage time, moisture, TSS, $\mathrm{pH}$, total and reducing sugars, and non-enzymatic browning were increased, while acidity, ascorbic acid, total carotenoids, phenols, total antioxidants, and crude protein contents of jam were decreased. The jams were still acceptable and free of microbial contamination during 3 months of storage time. The average crude protein content during storage of fortified papaya jam was $4.16 \%$ (dwb) while control was only $3.15 \%$ (dwb). Both fortified papaya jam and control showed decreasing of acceptability during storage time with average of 8.0 and 8.3, respectively. Protein fortification using soya bean as material was considerably cheap. However, with the composition used in this research showed only able to increased the protein value by $33.3 \%$. Application of fortification using soya protein in papaya jam for healthier and cheaper products still need further studies.

\section{References}

Ajenifujah-Solebo SO \& JO Aina (2011). Physicochemical properties and sensory evaluation of jam made from black-plum fruit (Vitex doniana). African Journal of Food, Agriculture, Nutrition and Development, 11(3). 4774.

Anju B, KR Kumari, V Anand \& MA Anjum (2014). Preparation, quality evaluation and storage stability of peach-soy fruit leather. SAARC J Agric 12(1), 73-88.

AOAC (1990). Official Methods of Analysis (Vol.2). Gaithersburg, Md, AOAC International.

Asikin Y, A Kamiya, M Mizu, K Takara, H Tamaki \& $\mathrm{K}$ Wada (2014). Changes in the physicochemical characteristics, including flavour components and Maillard reaction products, of non-centrifugal cane brown sugar during storage. Food Chem 149, 170-177.

Barlianti V, D Dahnum, E Triwahyuni, Y Aristawan \& Y Sudiyani (2016). Enzymatic hydrolysis of oil palm empty fruit bunch to produce reducing sugar and its kinetic hidrolisis enzimatik tandan kosong kelapa sawit untuk menghasilkan gula pereduksi dan kinetikanya. Menara Perkebunan 83(1), 37-38. 
Bons HK \& SS Dhawan (2013). Studies on preservation of guava pulp. Indian J Hort 70(3), 452-454.

Boshra V \& AY Tajul (2013). Papaya-an innovative raw material for food and pharmaceutical processing industry. Health Environ 4(1), 68-75.

Damiani C, FA da Silva, ER Asquieri, ME Lage, V Boas \& EV de Barros (2012). Antioxidant potential of Psidium guinnensis Sw. jam during storage. Pesquisa Agropecuária Tropical 42(1), 90-98.

Fracassetti D, C Del Bo', P Simonetti, C Gardana, D Klimis-Zacas \& S Ciappellano (2013). Effect of time and storage temperature on anthocyanin decay and antioxidant activity in wild blueberry (Vaccinium angustifolium) powder. J Agric Food Chem 61(12), 2999-3005.

Gomes MH, T Vieira T, JF Fundo \& DPF Almeida (2014). Polyphenoloxidase activity and browning in fresh-cut 'Rocha'pear as affected by $\mathrm{pH}$, phenolic substrates, and antibrowning additives. Postharvest Biol Technol 91, 32-38.

Gulliksen J (2018). The trend of being vegetarian: A comparative case study of how social norms affect meat-consuming behavior. Lund Universities Libraries, Lund.

Gupta E, S Purwar, P Jaiswal, R Chaturvedi \& GK Rai (2016). Sensory evaluation and nutritional composition of developed papaya-gooseberry jam. Food and Nutrition Sci 7(07), 600.

Hulme AC \& R Narain (1931). The ferricyanide method for the determination of reducing sugars: A modification of the Hagedorn-Jensen-Hanes technique. Biochem J 25(4), 1051.

Hutchinson MJ, JR Ouko, J Ambuko, WO Owino \& J Subramanian (2018). Effects of hexanal dip on the post-harvest shelf life and quality of papaya (Carica papaya L.) fruit. The J Faculty of Food and Agric 41, 43-44.

Jiang J, Z Zhang, J Zhao \& Y Liu (2018). The effect of non-covalent interaction of chlorogenic acid with whey protein and casein on physicochemical and radical-scavenging activity of in vitro protein digests. Food Chem 268, 334-341.

Karanjalker GR, DB Singh \& VB Rajwade (2013). Development and evaluation of protein enriched guava nectar blended with soymilk. The Bioscan $8(2), 631-634$.

Kaul S (2017). Process Development for Preparation of Toffee from Figs. Punjab Agricultural University, Ludhiana.

Khan RU, SR Afridi, M Ilyas, M Sohail \& H Abid (2012). Development of strawberry jam and its quality evaluation during storage. Pakistan $J$ Biochem Mol Biol 45(1), 23-25.

Kuchi VS, R Gupta \& S Tamang (2014). Standardization of recipe for preparation of guava jelly bar. J Crop and Weed 10(2), 77-81.

Leahy E, S Lyons \& RSJ Tol (2010). An estimate of the number of vegetarians in the world. ESRI working paper.

Luximon-Ramma A, T Bahorun \& A Crozier (2003). Antioxidant actions and phenolic and vitamin $\mathrm{C}$ contents of common Mauritian exotic fruits. J Sci Food Agric 83(5), 496-502.

Madeira-Nunes P, Vania, BS Vilela, E Erika, DCF Travassos, AV Delgado \& CN Brito (2007). Green umbu (Spondias tuberosa Arr. Cam.) preserve: Physical, chemical and microbiological changes during storage. $J$ Food Processing and Preservation 31(2), 201-210.

Majumdar KC \& SK Chattopadhyay (2011). Heterocycles in natural product synthesis. John Wiley \& Sons. New York

Mao X \& Y Hua (2012). Composition, structure and functional properties of protein concentrates and isolates produced from walnut (Juglans regia $\mathrm{L}$ ). International J Mol Sci 13(2), 1561-1581.

Menezes EW, CC Tadini, TB Tribess, A Zuleta, J Binaghi, N Pak \& BR Cordenunsi (2011). Chemical composition and nutritional value of unripe banana flour (Musa acuminata var. Nanicão). Plant Foods for Human Nutrition 66(3), 231-237.

Nour AAM, KSM Khalid \& GAM Osman (2011). Suitability of some Sudanese mango varieties for jam making. Am J Ind Res 2, 17-23.

Oksuz T, E Surek, Z Tacer-Caba \& D Nilufer-Erdil (2015). Phenolic contents and antioxidant activities of persimmon and red beet jams produced by sucrose impregnation. Food Sci Technol 3(1), 1-8.

Paramita V, K Iida, H Yoshii \& T Furuta (2010). Effect of additives on the morphology of spraydried powder. Drying Technol 28(3), 323-329.

Perez-Rocha KA, N Guemes-Vera, A BernardinoNicanor, L Gonzalez-Cruz, JP Hernandez-Uribe \& AT Sanchez (2015). Fortification of white bread with guava seed protein isolate. Pakistan $J$ Nutrition 14(11), 828.

Pinandoyo DB, S Siddiqui \& MK Garg (2019). Physico-chemical analysis of protein fortified papaya jam. Jurnal Al-Azhar Indonesia seri Sains dan Teknologi 5(1), 50-55.

Poiana M-A, D Moigradean, D Dogaru, C Mateescu, 
D Raba \& I Gergen (2011). Processing and storage impact on the antioxidant properties and color quality of some low sugar fruit jams. Romanian Biotechnol Lett 16(5), 6504-6512.

Rangnna S (2007). Handbook of analysis and quality control for fruits and vegetable products. Tata Mcgrawhill. NewDelhi

Rawat S (2015). Food Spoilage: Microorganisms and their prevention. Asian J Plant Sci Res 5(4), 4756.

Rivera-Vélez SM (2016). Guide for carotenoid identification in biological samples. J Natural Prod 79(5), 1473-1484.

Rodriguez-Amaya DB (2001). A guide to carotenoid analysis in foods (Vol. 71). ILSI press, Washington.

Safdar MN, A Mumtaz, T Hameed, N Siddiqui, S Khalil \& M Amjad (2012). Storage studies of jam prepared from different mango varieties. Pakistan J Nutrition 11(7), 555-561.

Shahidi F \& P Ambigaipalan (2015). Phenolics and polyphenolics in foods, beverages and spices: Antioxidant activity and health effects-A review. J Functional Foods 18, 820-897.
Sharma DS, RK Kaul, A Bhat \& J Singh (2016). Quality evaluation and storage stability of jamunmango blended squash. The Horti Soc India (Regd.) 73(1), 153-156.

Singh R \& S Siddiqui (2010). Standardization of processing technology for jamun (Syzygium cumini L.) jam and chutney. Haryana J Horti Sci 39(3/4), 263-265.

Wang H, LA Johnson \& T Wang (2004). Preparation of soy protein concentrate and isolate from extruded-expelled soybean meals. J American Oil Chem Soc 81(7), 713-717.

Wani RA, VM Prasad, SA Hakeem, S Sheema, S Angchuk \& A Dixit (2013). Shelf life of Karonda jams (Carissa carandas L.) under ambient temperature. African J Agric Res 8(21), 24472449.

WHO (2006). The role of food fortification in the control of micronutrient malnutrition. Guidelines on Food Fortification with Micronutrients. World Health Organization.

Wu G (2016). Dietary protein intake and human health. Food \& Function 7(3), 1251-1265. 